\title{
自律神経失調症の外来診療 (9)
}

\section{一一多元的治療にて患者の病を開放する—}

$\begin{array}{cc}\text { 東京都 今井医院 } & \\ & \text { 今 } \text { 井 }\end{array}$

\section{4. 不眠症}

自律神経失調症には必ずといって良いが よく眠れないとか, 睡眠が浅い, すぐ目が 覚めるなどの訴えがある．それらのパター ンは次の 3 つに分けられる。 (1)寝つけない， (2)一旦寝ついてもすぐ目が覚めてしまう，(3) 寝た気がしないといった 3 つである．私自 身も 50 歳前後にこんな症状になり，ネルボ ンなどの睡眠薬をのんでも全然効果なく，困 り果てたことを経験した。こんな時には覚 醒神経が極端に興奮しているので何をして も駄目なのであろう。しかし，人間という ものは，そういつまでも眠らないではいら れない．ある時期がたつと眠れるようにな る.マウスをつついて，眠らせないように すると 1 週間もすると死んでしまうそうで ある．人間はそうなる前に眠ってしまう。し たがって，患者が眠れないといってきても， 大丈夫，いつかは必ず眠れますよと自信た つぷり話すことにしている. 医学的な治療 としては，最初は就眠剤を数日使用するに しても，途中でやめさせて，肩のこりをと るとか, 頸椎がずれていたら調整するとか, 理学療法をすすめることにしている. 就眠 前足湯を $20 \sim 30$ 分やるのも大変効果があ る.

睡眠については 2 種類あることがだいた い解明されている。一つは脳波に睡眠特有 のゆっくりした波形があらわれる深い眠り
で身体のすべての働きが低下し，肉体を休 め疲れをとるためのもので，もう一つは睡 眠中に眼球が速く激しく動くレム睡眠と呼 ばれるもので脳波も覚醒時と同じもので夢 はこの時に見ている．深い眠りとレム睡眠 が一組となり，90 分おきに 4 回から 5 回繰 り返されるのが一晚の睡眠である．精神的 なものが不眠症の原因になっていることが 多いので，身体的な運動も効果がある．鍼 负を用いると大変効果のあることも経験さ れている。つぼとしては，行間と百会がよ い。他に神門，中脘，風池，身柱を併用す るとな扔効果がある．行間は足の親指と第 二指の間にある．親指と第二指のつけ根の 親指側の骨側の所で強く押すとしびれるよ うに痛む所があるが，そこが行間のつぼで， 銀粒を貼っておき，䙦る前に上からマッサ 一ジすれば効果があるし，令を 3〜5 壮やる のもよい.また頭のてっぺんの百会に炎を 3〜 5 壮やるのもよく効く，百会は，耳の線 をまっすぐに上にひき，頭上のまん中の線 であう所で，圧痛がある。

アトラスオーソゴナル法により，アトラ スの調整ないし，頸椎の調整も場合によっ ては必要となる。

まず日常生活を規則正しくし，姿勢をま つすぐにする。呼吸も小さなうわずった呼 吸ではなく, 呼主吸従の, 長い呼気でゆっ たりと行うように習慣づける。私の坐禅の 師の平井玄恭禅師が，かつて，話しておら 
れたが，「新入社員の坐禅会を頼まれてやっ てみると，一流会社の社員はさすが姿勢が 皆きっちりとして良いが，二流，三流とな ると，姿勢がわるく，変な格好で座るのが 多い.きちっと結跏跌坐をすると，おのず とよい姿勢になるものだ」とよくおっしゃ っていた。よく眠れないときに寝坐禅とい って，寝た姿勢で，長い呼気を 1 から 10 ま で数え，また繰り返すことをやると，いつ のまにか寝てしまう。白隠禅師の内観法お よび軟酥鴨卵の法は，これらに大いに役に 立つと推定される。

われわれの普段の呼吸は無意識に行って おり無関心でなおざにりしがちである。こ の重大さに気がついたのが釈尊と白隠と藤 田霊斉師であった，落ち込んでいる時は顎 をつきだして前かがみで浅い呼吸を何回も している，少し丹田呼吸に習熟すると普通 1 分間に 18 回くらいの呼吸が $1 / 3$ の 6 回位 で十分済むようになる，正しい呼吸は呼主 吸従の呼吸が最もよい方法であることが最 近わかってきた，出る息には心をこめて努 力するが入る息には心を放つ。こうすると いつまでたつても疲れない. 坐禅の時の呼 吸も数息観にしろ，随息観にしろ呼気に注 目し，気海丹田に力をこめてゆく，すなわ ちまず形を整え，呼吸を整え，そうして心 を整える。こうすることによって，コップ の中の泥水がすんでくるように，ほんとう の自己がわかってくるし，これが最も頼り になるものである．法句経に「おのれこそ おのれのよるべ おのれを措きて 誰によ るべぞ よくととのいし おのれにこそ ま ことえがたき よるべをぞ獲ん」とある，誠 にもって良い教えと考える，坐禅によって， よくおのれを整えると, 精神的にも, 肉体 的にも安定してきてさわやかとなる.
沼津から国道を左に三保の松原の松林を 見ながら，しばらくゆくと田圃のまん中に ぽつんと松陰寺がある．門前に大きなため きの像がおかれてあり，酒どっくりをぶら さげている.かつて白隠禅師が住職として 多くの雲水を指導した寺である. 駿河に過 ぎたるものは「富士の山と白隠」とうたわ れたくらい, 五百年不世出の禅僧として 人々に慕われた。白隠禅師は, 貞享二年十 二月二五日，富士山の裾野近く原の宿で生 れ育った. 幼名を岩次郎といい， 3 歳まで は歩くこともできないほどの病弱であった という。しかし頭脳はすばらしく，記憶力 は抜群であった. 14 歳で原の松陰寺の単領 和尚のもとで得度し, 名を慧鶴と改めて修 業が始まった。各地の各僧といわれる人を 求めて掛錫し，教を受けたが最も深く師事 したのは信州飯山の正受老人であり，彼の 許で大悟した，時に 25 歳であったが，悟後 の修業が大事とされ，郷里に帰り修業に励 んだ。粗食で体力も低下したうえ，睡眠不 足，ノイローゼが重なり，その上結核に侵 されたらしい.「心火逆上, 肺金焦枯」と彼 は表現している，歯を食いしばり，両眼を かっと見開き，大きく息を吸い込んでは，そ の息を止めた。これが患いとなって寝ても さめても種々の幻覚に教われ，「両腋常に汗 を生じる」と，自分の病気はもはや鍼负や 薬では治すことができないと知り, 修業し ながら名僧, 知識を求め, 旅に出, 京都郊 外の白河山中に住む白幽仙人に会うことが でき，䋅法を伝授してもらう。さっそく実 践に移したところ，三年も経たぬうちに苦 しめられていた多くの症状をすべて除き去 ることができ, 84 歳でこの世を去るまで健 康体で過ごせたという.

時に 26 歳で, かつての自分と同様禅病に 
苦しむ雲水達にその祕法を授けた。やがて それが噂を呼び幻の名作として求められ「夜 船閑話」という著書が誕生した。 その評判 を聞いて京都の小川という本屋から手紙が きて, やがて小川書店から宝暦七年出版さ れ，当時においてもその反響は極めて大で あった。爾来禅の宗門における修業僧のみ ならず，広く一般の人々にも読まれ続け，明 治, 大正, 昭和, 平成となった現在もその 名声は広がりつつあり, その力強い治病体 験録は多くの人々の心を打つものがあり，二 百年にも及ぶロングセラーとなっているゆ えんと考えられている。

夜船閑話の中で彼が白幽仙人に教わった とされる祕法は, 次のように記されている。 各種の内観法が出てくるが，まず軟酥鴨卵 の法について述べると修業するものが禅定 中に四大が調和せず，身心ともに疲労して いることに気がついたときは，次のような 観相をすすめている．たとえばいろも香り も清らかで軟らかな，そして滋養たつぷり の酥の鴨卵大のものを頭上にしかと置くと 仮定する。その気味は微妙で，それが丸い 頭蓋骨を通して脳をうるおし，それが次第 に浸々として水が浸すがごとく下へ降りて きて，両肩および両腕に及び，さらには左 右の乳から胸中の心臓および，そして腹腔 内の胃, 腸, 肝, 腎, 脾, さらに背骨, 尾 骨までも次第にうるおしてゆく。このとき に実は五臓六腑の血液の帯りや疝病塊痛な どが心に随って降りてゆくこと，水が低き につくがごとくに消えていくことがはっき りわかる，かくして軟酥の溶けたものが全 身をめぐり流れ，さらに両脚まで緩かにう るおしながら最後に足心でとどまる、「修業 者はこの観想をたびたび実行されよ。そう すれば五蔵六腑の気血の滞りはとけて消え，
胃腸は調和し，知らぬ間に肌の色がつやつ や光沢を生ずる」と.ドイツの「シュルツ の自律訓練法」もこの想念を用いた方法で ある，次に内観の秘法であるが，一切の工 夫を中止してまずよく眠り，それからゆっ くり起きる。そして眠りに入らないうちに 両脚を伸ばし，しっかり踏みそろえる。そ して全身の元気を臍下の気海丹田に込め, さらに腰脚から足心まで充実させる。その ときに次のような観念をすることだ．原文 のとおり記すと,「(1)我が此の気海丹田, 腰 脚足心総に是我が本末の面目, 面目何の鼻 孔かある. (2)我が此の気海丹田總に是我が 本文の家郷，家郷何の消息かある。(3)我が 此の気海丹田, 総に是我が唯心の净土, 浄 土何の荘厳かある。(4)我が此の気海丹田, 総に是我が己身の弥陀, 弥陀何の法をか説 $<$.

このように繰り返し観想すると，一身の 元気が気海丹田の下腹部ばかりでなく腰脚 足心といった下半身全体に充実してくる，そ の結果臍の下にひごのような膨みが生じ，し かも下腹部は篠竹で打つとはねかえってく るような鞠のようにきりっとしまってくる. 白隠はもしそうした治療力が現れなかった ら，わが頭を切り持ちされとまでいった自 信のほどがうかがわれる，夜船閉話の中の 白幽仙人が実在の人物であったかどうかに ついては疑問の点もあるようであるが，白 幽仙人が語り，白隠がそれを聞くという構 成については白隠の文章力のすばらしさを 示す。印度から伝わった佛教経典には如是 我聞という言葉で始まることが多いが，こ のあたりからヒントを得たのであろうか. 彼 はさらに動中の工夫は静中の工夫に勝るこ と百千億倍と唱えた。修業は動禅, 静禅の 二境をもって初めて成立するという白隠の 
見方である. 寺院内の作務も托鉢も歩行行 脚もすべて動禅と考えた. 19 歳から 32 歳ま でに掛錫した禅寺は十指をこえるが，この 間の行脚, 坐禅, 作務, 日常生活すべて活 力禅といえる. さらに白隠はその後, 各地 の禅寺での講演で提唱をつづけ 84 歳で止寂 するまで動きつづけたといっても過言では ない. 白隠が生み出した「ひさご腹丹田呼 吸法」では呼吸時, 䐮下邰然, つまり胸を 軽くしながら，下腹部を充実させる長呼息 なので，ひょうたん型となる，上部清涼，下 部温暖 心をこめて息を吐き出すことによ り頭も胸もさわやかとなり，下半身が暖か くなる.

東大分院の笠松教授による坐禅と脳波の 生理学的研究では, 熟達した各僧になるほ ぞ, $\theta$ 波がすぐ出てくるとされて知識人の興 味を集めたことは有名である。私は交感神 経の興奮性を表すとされている 良導絡グ ラフを 1 時間の坐禅前後で測定してみると， 熟練者は $\mathrm{H}$ 系が生理的範囲内の上限に, $\mathrm{F}$ 系が下限に集まってきてれのような型が できあがる。興奮性が調整されたと考えて よい. 初心者はまた別の反応を示す. 長呼
気丹田呼吸により腹圧がかかり, 腹腔から 心臟への静脈還流が増え, したがって分時 送出量が増加し, 身体のすみずみまで血液 がゆきわたる。つまり $\mathrm{CO}_{2}$ を十分に吐きす て, 組織の中に大量の $\mathrm{O}_{2}$ を送り込むことが 一つと, 腹圧をかけることによって上腹部 にある太陽神経叢を刺激し, 自律神経系の 働きを調整するのを二として, 以上の二点 に作用機序を求めてよいと考えられる.

\section{・良導絡専用カルテの読み方および反応良 導点の探索法}

77 巻 4 号に記録の実際について述べたが, こうして出来たカルテをどうやって読みと るかについて記したいと思う. $1.4 \mathrm{~cm}$ の生 理的範囲を超えたものを興あるいは抑とし， 各良導絡の興奮性を電気的に知ることがで きることはすでにのべた通りである．まず 24 本の平均值についてであるが, 全般的に 高い場合は室温が高いか, 若い人の時が多 いが，年齢による電流量と比較してもなお 高い場合は交感神経緊張型といい, 逆に低 い場合は交感神経緊張低下型といい, 主と して老人に多い.

\section{表 1 生理的平均電流量と年齢および室温の関係}

\begin{tabular}{|c|c|c|c|c|c|c|c|c|c|c|c|c|c|c|c|c|c|c|c|c|c|c|c|c|}
\hline \begin{tabular}{|l|} 
室温年代 \\
\end{tabular} & 10 度 & 度 & 12度 & 13 度 & 14 度 & 5 度 & 16 度 & 17 度 & 18 度 & 9度 & U/ & & & & 摭 & 5度 & & & & & & & 32度 & 33度 34 度 \\
\hline 10代 & 46 & 48 & 50 & 52 & 55 & 57 & 59 & 60 & 60 & 61 & 62 & 63 & 63 & 64 & 65 & 66 & 68 & 70 & 72 & 80 & 87 & 89 & 90 & \\
\hline 20 代 & 42 & 44 & 46 & 48 & 51 & 53 & 55 & 56 & 56 & 57 & 58 & 59 & 59 & 60 & 61 & 62 & 64 & 66 & 68 & 76 & 83 & 85 & 86 & \\
\hline 30 代 & 38 & 40 & 42 & 44 & 47 & 49 & 51 & 52 & 52 & 53 & 54 & 55 & 55 & 56 & 57 & 58 & 60 & 62 & 63 & 72 & 79 & 81 & 82 & \\
\hline 40代 & 34 & 36 & 38 & 40 & 43 & 45 & 47 & 48 & 48 & 49 & 50 & 51 & 51 & 52 & 53 & 54 & 56 & 58 & 59 & 68 & 75 & 77 & 78 & \\
\hline 50 & 31 & 33 & 35 & 37 & 40 & 42 & 42 & 45 & 45 & 46 & 47 & 48 & 48 & 49 & 50 & 51 & 53 & 55 & 56 & 65 & 72 & 74 & 75 & \\
\hline 60代 & 27 & 29 & 31 & 33 & 36 & 38 & 40 & 41 & 41 & 42 & 43 & 44 & 44 & 45 & 46 & 47 & 49 & 51 & $5 ?$ & 61 & 68 & 70 & 71 & \\
\hline ０代 & 23 & 25 & 27 & 29 & 32 & 34 & 36 & 37 & 37 & 38 & 39 & 40 & 40 & 41 & 42 & 43 & 45 & 47 & 48 & 57 & 64 & 66 & 67 & \\
\hline
\end{tabular}

1546 例より生理中央線電流量と年齢および室温との関係を求め, その曲線に修正を加えて室温, 年齢による生理中央 線電流量の平均値を求めた。生理中央電流量

(例) 30 代で室温が 18 度であれば生理中央線は $52 \mu \mathrm{A}$ が平均値となる. 
表 1 は中谷先生が 1546 例から求められた もので，それ以後こうした発表はみられて いない．たとえば 40 代で室温 20 度のとき， $50 \mu \mathrm{A}$ が平均電流量となる.この平均電流 量が高いときは急性疾患, 発熱, 発汗時て あり, 低いときは, 老年者, 病弱者, 慢性 疾患の衰弱期で，したがって疾病の盛衰の 参考となる．特に $F_{6}$ が 0 になると 3 日以内 に死亡することが経験されている．また電 流量測定の場合極端に少なくて興抑を求め 難いときは $21 \mathrm{~V}$ で測定して差を求める。

上肢で測定した電流量が平均に高く, 下 肢の測定值が低いということが一般に多い ので，このような型を一般型と呼んでいる. すなわち顔面および上肢は通電抵抗が，下 肢より低く，よく電流が通るのが普通であ る. 次に上肢の測定值が低く下肢が高い場 合は神経質な人が多いので逆型，または神 経質型と呼んでいる。

次に生理的範囲を超える興抑の所見から は次のような事柄を推定することができる. すなわち 77 巻 3 号に示した良導絡症候群の ゴシック体にした症状のほほ $80 \%$ 出現する と考えられている。したがって患者に症状 を聞かなくても，不問診と称して，症状を あてることに利用され得る，興抑が，上下 に数カ所, $1.5 \mu \mathrm{A}$ 以上のものがあると, ば らつきが多いと感じられ，かつまた患者の 症状が多彩であることを経験する。したが ってこのばらつきが多い場合，自律神経失 調症と考えて差し支えないように思われる. この点についてはまた，改めて論じるつも りである。一例をあげると $\mathrm{H}_{6}$ が高い場合は 肩のこりが著明のことが多い.また $\mathrm{F}_{2}$ が高 い場合は不眠とか怒るとか気分不快となり， $\mathrm{F}_{6}$ が低い場合はあくびがでてゆううつであ るなど，なるほどとうなずかれる。これら
の興抑を利用して漢方の証の決定するソフ トもできている.

\section{- 反応良業点の探索法}

身体のどこかに異常があると皮膚に反射 されて, 反応良導点が出るので, その探索 法についてふれたいと思う。反応良導点の

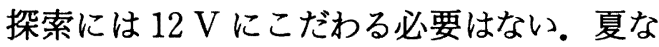
ど出すぎるときは $6 \mathrm{~V} に$ ，反対に冬など出 にくいときは $21 \mathrm{~V}$ にし, 電流量も決めなく てよい．周辺より良く電流が流れるのがわ かればよい，局所に反応良導点を求めるに は握り導子を患者の片手に握らせ，探索に 慣れないうちは，金属導子で探索してもか まわない，金属導子を用いると，反応良導 点以外の場所ではほとんど電流は流れない が, 反応良導点にくると突然電気が流れる。 この方法で反応良導点は容易に見つけられ るが, 患者は弱い電気ショックを感じる。し たがって少し慣れてきたら濕性導子の場合 は反応良導点と他の領域との電流の差は小 さく20〜50 $\mu \mathrm{A}$ である．鮮明にこれを発見 するには，患者の皮盧に直接に濕性導子を

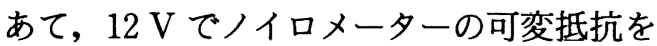
$200 \mu \mathrm{A}$ ぐらい流れるように調整しておく. 電極が反応良導点に触れた場合，だいたい $150 \mu \mathrm{A}$ くらい流れるので良くわかる. $12 \mathrm{~V}$ から $21 \mathrm{~V}$ に上げれば，探索が容易な場合が ある。

もしも同じ領域で電極を何回もなでまわ すと電流が刺激となり，どこでも電流が流 れやすくなる。これはまぎらわしくなるの で電極の効きはスムーズに同じ力でなでる 必要がある．またあまり多く出るときは電 圧を下げる，これは，ある程度練習と熟練 を要する. 反応良導点を探索するのに図1の ような(1)，(2)，(3)の 3 つの方法がある. 顔, 


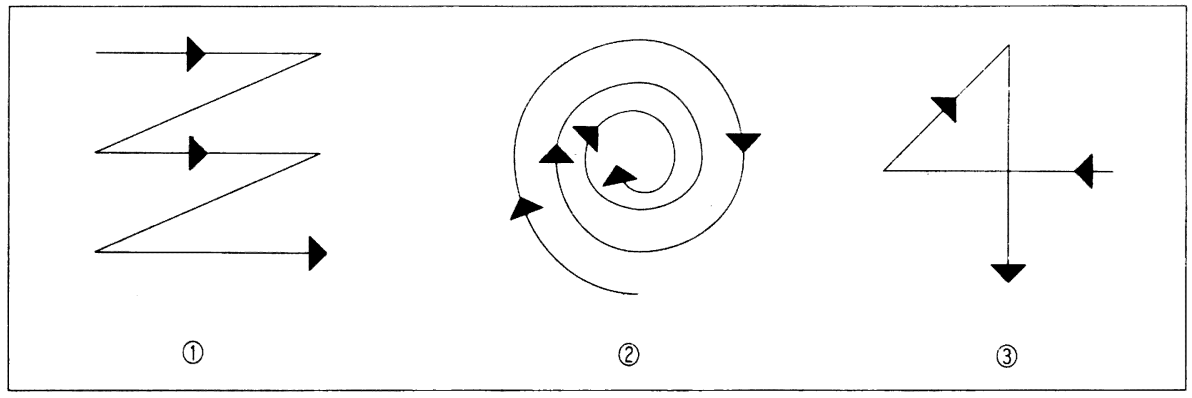

図 1 反応良等点探索法

頭など身体の上の部分では高い電流が流れ， 身体の下の部分では低い電流が流れること を承知しておく必要がある，したがって頭 では反応良導点は 150 を示すかと思うと， 下肢では 50 で，すでに反応良導点を示すこ ともあるので, 高さではなく, 周囲との比 較で決めるものであることを注意すべきで ある。

\section{5. 自律神経失調症の治療}

連載を終わるに当たつて，本症の治療方 法を整理しておきたいと思う。幸い昨年 11 月サンパウロ大学およびブラジル医師銊众 学会で講演する機会を得たので，その内容 を要約し，検討を加えた。

自律神経失調症とは，種々な自律神経性 の不定の愁訴を有し，しかも器質的な疾患 を見い出し得ず，顕著な神経障害のないも ので，その診断規準は既に本誌 77 巻 8 号に 詳述した。治療法については次の通り多面 的な対応が必要となってくる。

（价西洋医学的方法：薬物療法, 生活指 導, 心理療法

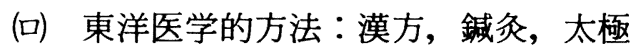
拳, 気功, 良導絡

（）手技療法：オステオパシー，カイロ プラクティック

(二) 温泉気候療法：転地によるストレス の解消新鮮な大気および自然に触れ る. 温泉成分の効果
（ホ）坐禅および丹田呼吸法：形をととの え，呼吸をととのえ，心をととのえ ることによって，心身の安定を得る。

( 食養生：新鮮な野菜および魚を主と し，旬の「気」の多いものをできる だけ食べる，特に自然農法による野 菜，果物がよい。ある時には玄米を すすめ，肉食を制限する。

以上の詳細については既述してあるので 参考にしていただきたいと思う。

以下良導絡法を要約し，本症によくみら れる個々の症状である, 頭痛, 肩こり, 眩 暈, 不整脈, 胃腸障害, 低血圧などの治療 点について示し(表 1, 2, 図1〜8), 東西医 学の相違点に言及する.

表 1 良劕絡治療法

(1) 興抑の調整 General regulatory treatment of the total Ryõdõraku (GRT)

(D) 基本治療点Fundamental treatment point (FTP)

(1) 局所の治療 Reactive electro-permeable poi nt treatment (REPP)

表 2 刺激方法, 治㙩回数

(1) 刺激方法 直流通電による電気針，イオン粒, 電気温尒，置針，モグサによる尒 療法, 低周波通電等

治療回数 第 | 週目は毎日もしくは|日置，? 週目は週 2 回, 3 週目は週 2 回, 4 週目からは週1回で10回を1クー ルとする.

注：通院できない時は众点を教えて自宅で尒療法, 集毛針を用いる。 

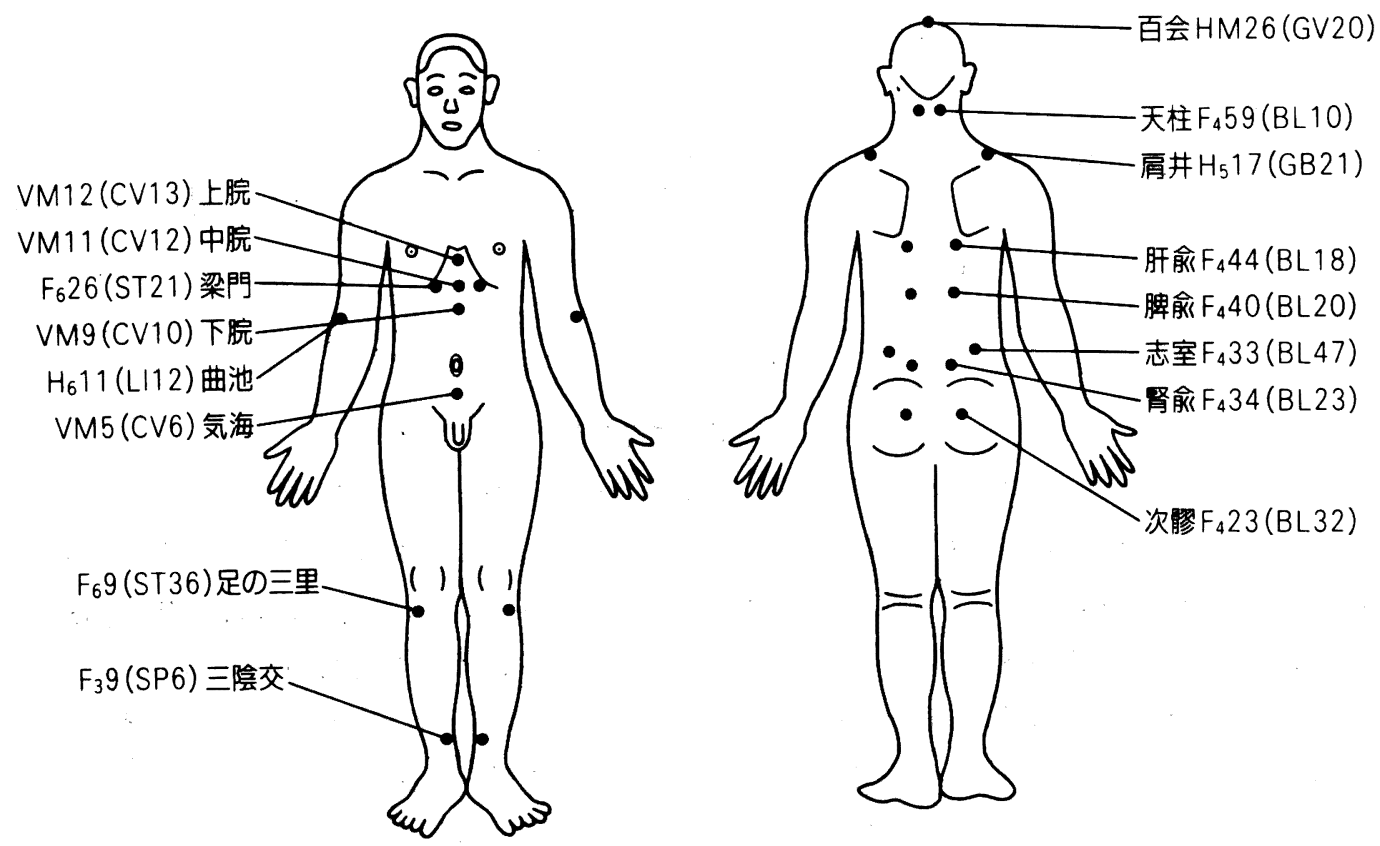

図 1 基本治灙点
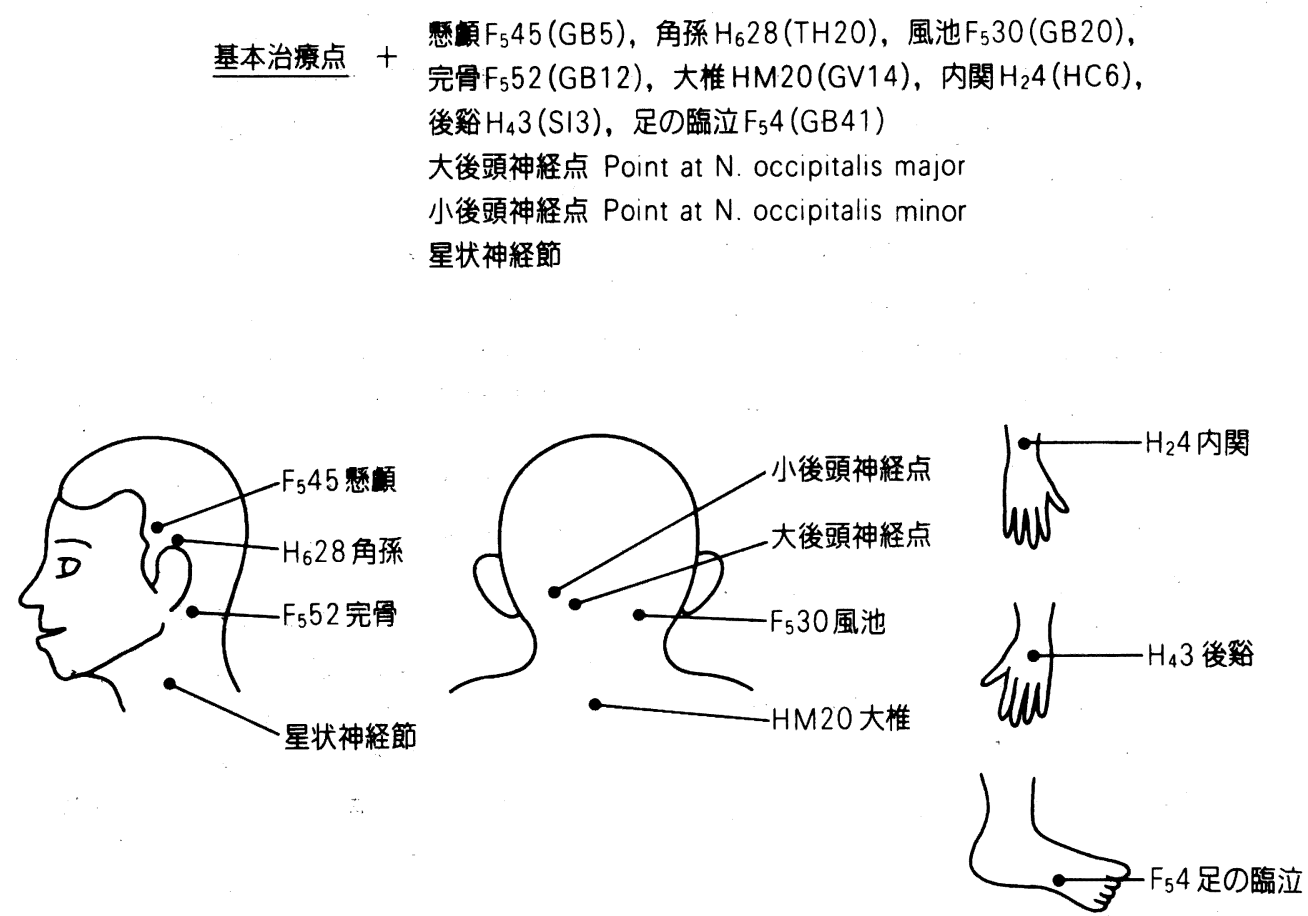

因 2 頭䑶 HEAD ACHE 


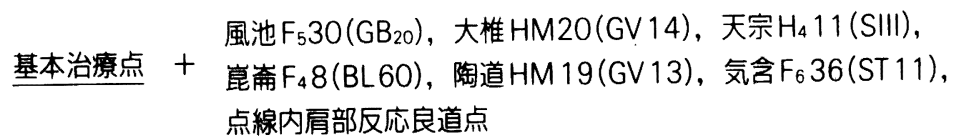
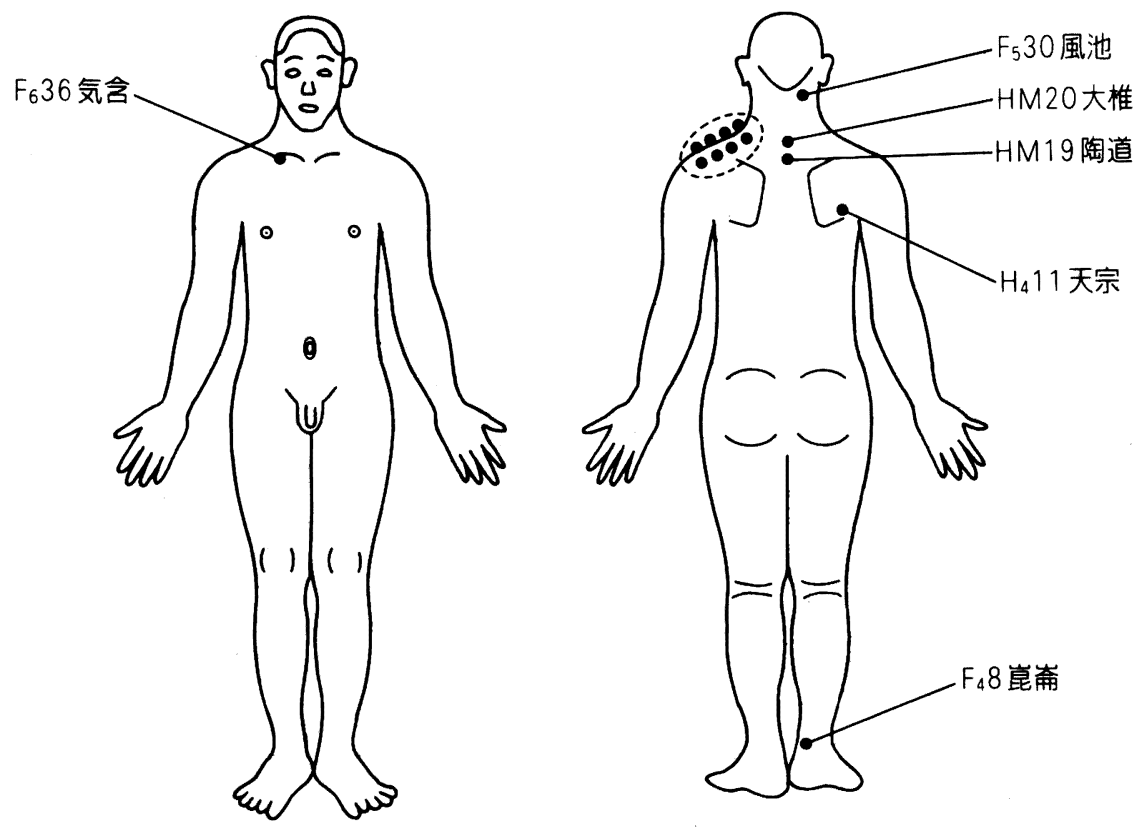

因 3 扁こり Schoulder stuffiness

基本治療点 $+\begin{aligned} & \text { 完骨 } F_{5} 52(G B 12) \text {, 風池 } F_{5} 30(G B 20) \text {, 天枢 } F_{6} 22(S T 25) \text {, } \\ & \text { 中極 } V M 2(C \vee 3) \text {, 委中 } F_{4} 14(B L 54) \text {, 膻中VM16 (CV17), }\end{aligned}$ 風市 $F_{5} 14$ (GB31)
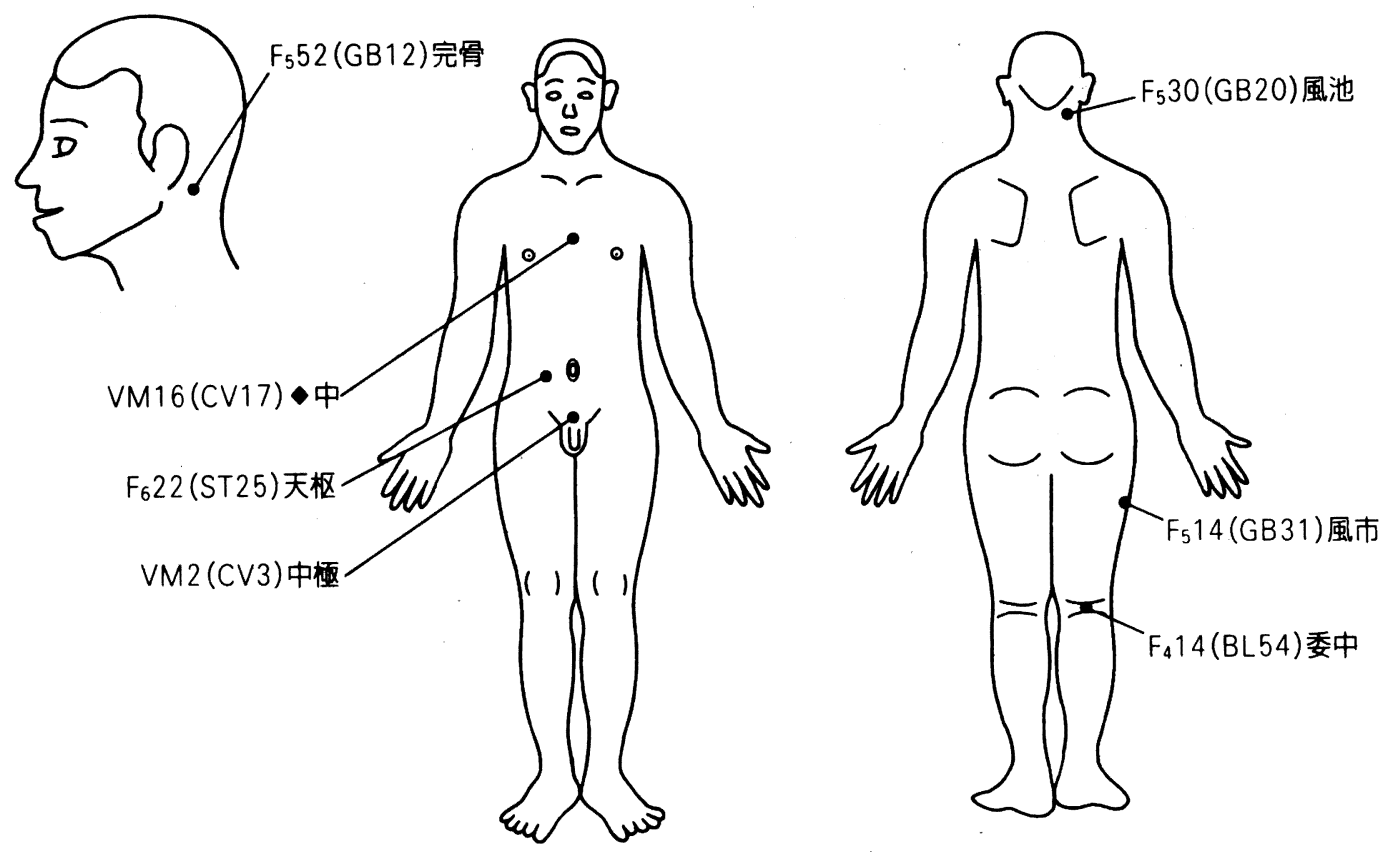

図4 眩番 VERTIGO 
基本治療点 + 膻中VM16 (CV17), 心俞 $\mathrm{F}_{4} 48(\mathrm{BL} 15)$, 神道 HM15 (GV11), 霊台 $H M 14\left(\right.$ GV10), 神門 $H_{3} 3(H T 7)$,
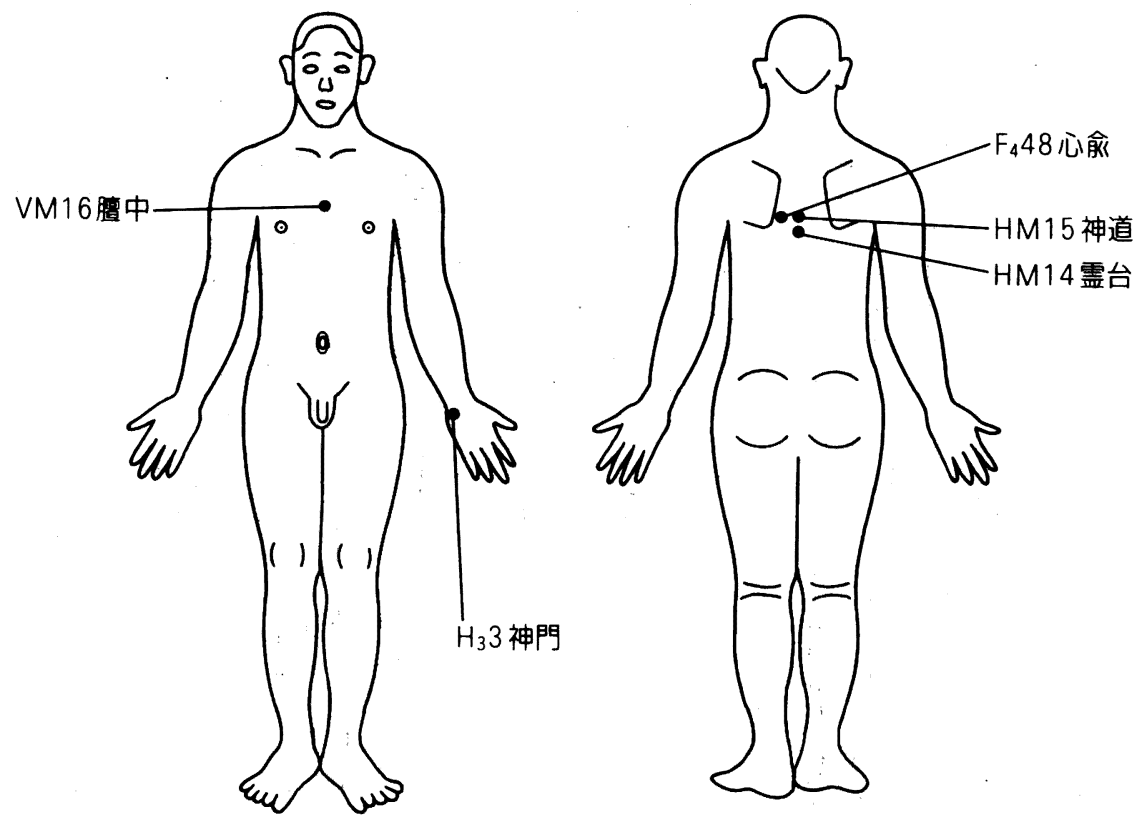

図 5 低血圧 Low blood pressure

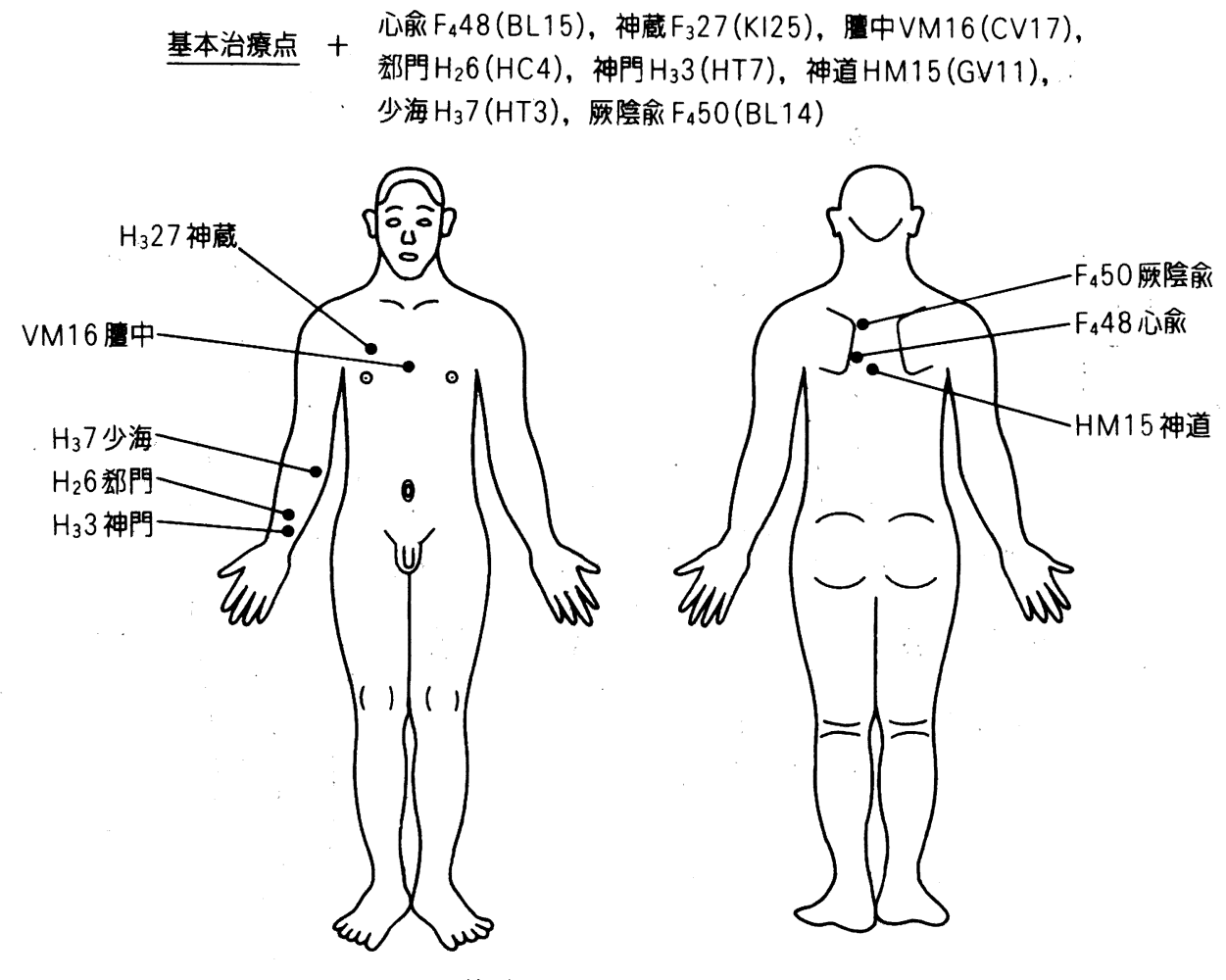

図 6 不整脈 Arrythmia 動楼 Palpitation 


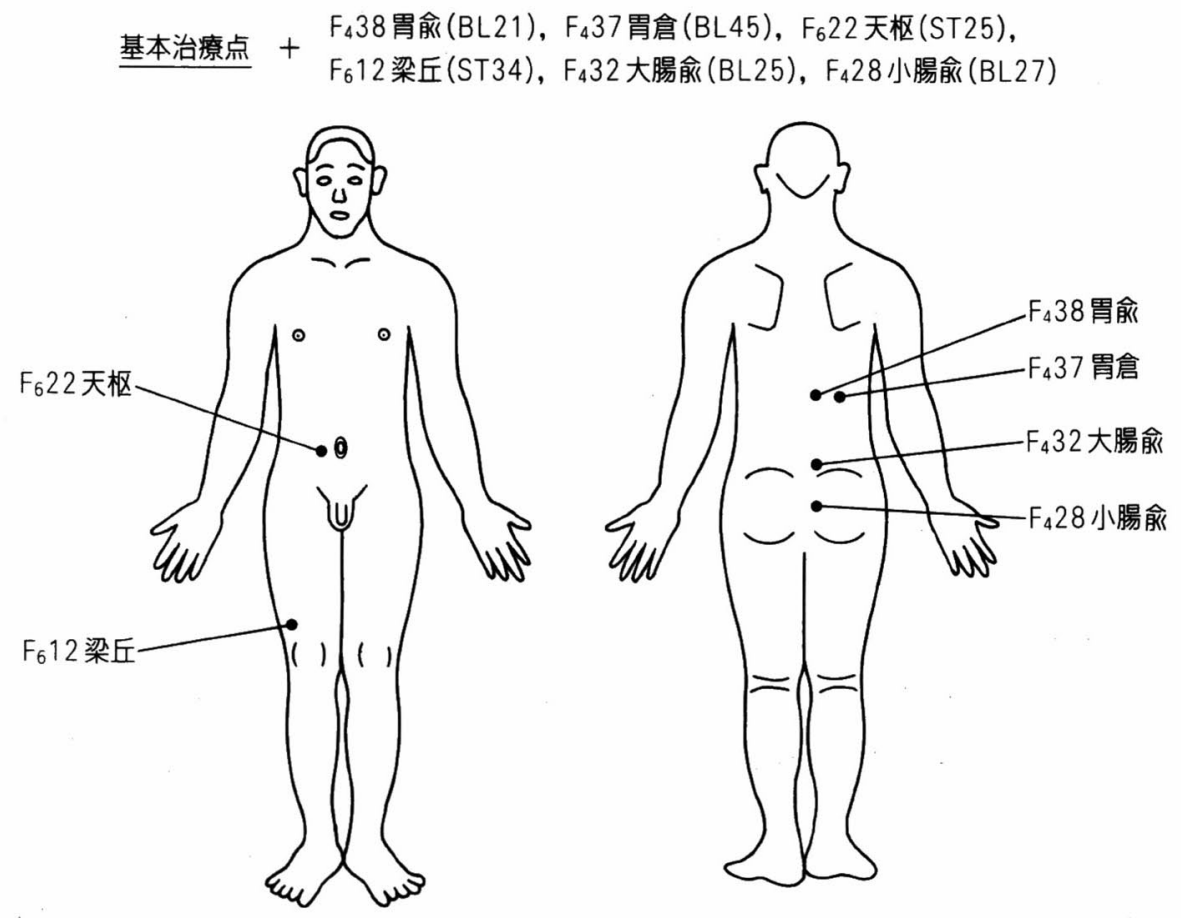

図 7 胃腸障害 Gastrointestinal disorder

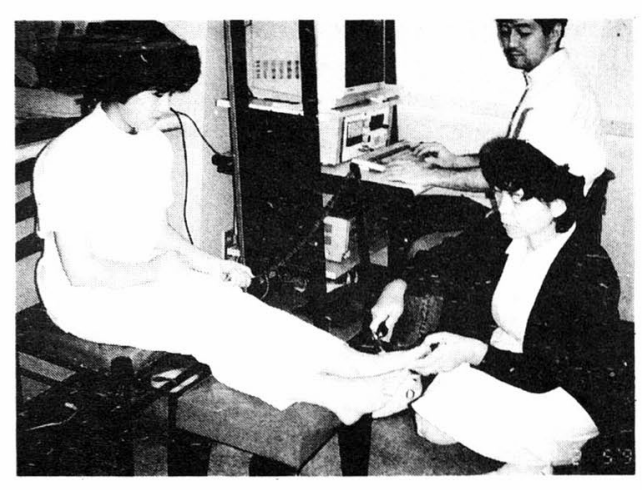

F 系代表測定点

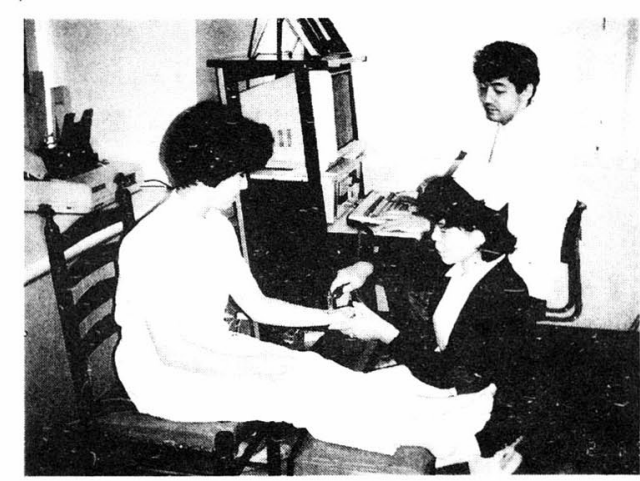

$H$ 系代表測定点

図 8 良導絡測定 (コンピュータ使用)

\section{- 東西医学の相違}

医学の発達の歴史, 環境の相違からして, おのずとアプローチの方法が異なる. 西洋 医学では, 最新の生理学, 生化学, 遺伝学 などを駆使して, 病名決定のために, 尿, 血液, 心電図, 脳波, レントゲン, 超音波 CT, MRI など諸検査を用いる. もちろん聴 打診もするが, 臓器がはれているか, 体腔
に水が溜まっているか, 臟器の位置が正し いかなど, 主に臓器の異変に注目する。ド イツの病理学者ウィルヒョウの創始になる 病理解剖所見をもととした臓器診断と病名 決定を治療のめやすとする。

これに反し, 東洋医学では, 患者の内藏 病変が体表に反射されて反応している皮膚 の所見をもととして治療をすすめる。この 
場合病名の決定は特に必要でない，皮膚の 硬さ，弾力性，むくみ，緊張度，反応良導 点などを手がかりとする。つまり視覚のみ でなく，触覚を大いに働かせる，中医学お よび中医学の影響を受けた日本の伝統医学 の漢方，鍼负療法は，脈診，腹診，舌診な どを通じて，主に皮膚や筋肉のこり，圧痛， 腫脹を通じて証を決定し，治療する，西洋 においても 19 世紀，ロンドンの内科医のマ ッケンジーがはじめて言い出した内蔵皮膚 反射学説があるくらいで，良導絡は近代的 生理学的手法を用いてこれを反応良導点と してとらえ, 経絡学説を学問的に裏づけた。 圧痛, 腫脹のある部分は通電抵抗が減弱し ており，易電導性で，交感神経が興奮して いる部分なので, 知覚過敏で治療点として は最も適切である.

ここで実例をあげ，東西医学のアプロー チをくらべてみることにする.今より数 10 年前のこと, 40 歳の腎性高血圧で, 数力所 の病院で不治と言われ，来院した．降圧剤 の使用とともに，腎経の“つぼ”である腎 俞, 復溜, 湧泉に 5 壯のお负をするように すすめた．本人は一生懸命でお负に精出し， ベテランとなり，他人に负をやってやるよ うになった. そのうちに病勢が変ってきて, つい最近まで元気で通院していた。たまた ま腎蔵結石と糖尿を合併していることがわ
かったので，専門医に紹介，転医した。 と もかく $2 \sim 3$ 年の命といわれた患者が 20 年 元気でいたのである。またある主婦で，染 色の専門家の方が, 最低血圧が上って苦し く心配だと電話をかけてきたので, とにか くいらっしゃいと来院させて診察してみる と, 顎から肩にかけてこりがひどく，良導 絡を用いてそのこりをとってやったら，ス ーッと楽になり，最低血圧が正常化した。 こういう例はしばしば経験するので肩こり の治療は血圧の安定に貢献する．高血圧の 治療で降圧剤その他を用いて血圧が正常化 しても, なおかつ肩こり, 背筋痛, 頭痛, 頭重感がとれない場合は, 高血圧による症 状と思っていた患者にとって意外であり，こ うした場合銊尒の併用によって苦痛をとり 除くことができる、また低血圧症にみられ る種々の訴えは薬剤は無力で, 東洋医学的 方法によって消失させることができる，自 律神経失調症においてもしかり，筋肉のこ りや，圧痛をとり除いてやることにより，も との病気の改善にもつながってくる.すな わち西洋医学的方法により, 癌とか, その 他の見落としてはいけない疾病を除外して 後, 東洋医学的方法を併用することが最善 のように思われる。この際，米国において 発達した手技療法家による骨盤, 椎骨, 頭 骨の調整も 1 枚加えるべきであろう。

文

1) 今井力：坐禅と丹田呼吸. 日本良導絡自律神経雑誌, 平成 6 年 3 月, 1994 .

2）中谷義夫：良導絡自律神経調整療法. 良導絡研究所, 1973 年. 